DEMOGRAPHIC RESEARCH

VOLUME 32, ARTICLE 59, PAGES 1603-1630

PUBLISHED 18 JUNE 2015

http://www.demographic-research.org/Volumes/Vol32/59/

DOI: 10.4054/DemRes.2015.32.59

Research Article

\title{
A resurgence of black identity in Brazil? Evidence from an analysis of recent censuses
}

\section{Vítor Miranda}

\section{(c)2015 Vítor Miranda.}

This open-access work is published under the terms of the Creative Commons Attribution NonCommercial License 2.0 Germany, which permits use, reproduction \& distribution in any medium for non-commercial purposes, provided the original author(s) and source are given credit.

See http:// creativecommons.org/licenses/by-nc/2.0/de/ 


\section{Table of Contents}

1 Introduction 1604

2 Racial statistics in Brazil 1605

3 Earlier studies and open questions 1607

$4 \quad$ Analytic strategy and data 1611

$5 \quad$ Results 1614

$6 \quad$ Alternative scenarios: Mortality, international migration, and 1620

$7 \quad$ Conclusions and discussion 1623

8 Acknowledgments 1625

$\begin{array}{ll}\text { References } & 1626\end{array}$ 


\title{
A resurgence of black identity in Brazil? Evidence from an analysis of recent censuses
}

\author{
Vítor Miranda ${ }^{1}$
}

\begin{abstract}
BACKGROUND

The second half of the 20th century brought a sharp increase in the number of people self-identifying as "brown" in the Brazilian Censuses. Previous studies have demonstrated that this was not the result of demographic forces, such as differential birth rates, but of a large number of people changing their response in the censuses from "black" or "white" to "brown". Despite the increased black political activism of the last two decades, whether this historical pattern of racial reclassification continued after 1990 has not yet been systematically investigated.
\end{abstract}

\section{OBJECTIVE}

This study investigates if the increase in identity politics by the Brazilian black movement since the 1990s was associated with a number of people changing their answers in the census from non-black to black.

\section{METHODS}

The residual method is used to estimate a counterfactual scenario: what the distribution of the population by race would look like in the 2000 and 2010 censuses if no racial reclassification had occurred during the 1990s and 2000s.

\section{RESULTS}

The "black" category experienced net gains of 2.2 million and 3.1 million newly reclassified members in the 2000 and 2010 censuses, respectively. By 2010 at least one in every three people in the black population was a newly reclassified black. The increase was particularly strong among males and the younger generations.

\section{CONCLUSIONS}

The historical flight from blackness in Brazil documented by previous studies has reversed in the last two decades. This suggests that the increased black activism might have been successful in valorizing black identity and increasing identification with blackness.

\footnotetext{
${ }^{1}$ Population Studies Center, The University of Pennsylvania. E-Mail: vitor@pop.upenn.edu.
} 
Miranda: A resurgence of black identity in Brazil? Evidence from an analysis of recent censuses

\section{Introduction}

The second half of the 20th century was marked by a sharp 'browning' of the Brazilian population in the country's national censuses. While the proportion of the population self-identifying as "brown" increased from 26\% to 43\% between 1950 and 1991, the proportion self-identifying as "black" or "white" declined from $11 \%$ to $5 \%$ and from $62 \%$ to $52 \%$, respectively. Ruling out differentials in fertility, mortality, or migration rates as potential explanations, previous studies have established racial reclassification as a driving force behind this trend: over their life course a significant number of people changed their response in the censuses from black or white to brown (Carvalho, Wood, and Andrade 2004; Wood and Carvalho 1994).

This pattern is consistent with the 'racial democracy' narrative. Its proponents argue that, in spite of the colonial history of enslavement of peoples of African descent in Brazil, cultural mixing and miscegenation between the Portuguese colonizers and the enslaved populations created a sense of a shared ancestry. As argued by Freyre (1966), over the course of the 20th century Brazilians would have come to largely consider themselves a racially mixed, brown population ${ }^{2}$.

However, two types of evidence suggest that this particular pattern of racial reclassification might have changed significantly in the last two decades. First, the racial democracy narrative has been strongly challenged by black activists since the end of the military dictatorship that ruled the country between 1964 and 1985. After the redemocratization of Brazilian society, social movement organizations were successful in pressuring the state to acknowledge the existence of racial discrimination and to pass specific legislation to address the issue (Hanchard 1999; Telles 2006).

Arguably, one of the most visible institutional changes was the introduction, starting in the early 2000s, of admission quotas designed to increase the participation of persons of African descent in universities and among civil servants. Following the categories used by the Brazilian Census Bureau, persons that self-identified as black or brown were eligible for the quota system. This came along with a broader set of policies implemented by the recently created Ministry for the Promotion of Racial Equality, which included legislation aimed to promote the culture and the well-being of the AfroBrazilian population (SEPPIR 2014). Previous studies have suggested that these policies might have had implications for identification with blackness, since, for instance, the mention of job quotas for blacks and browns in a split-ballot experiment

\footnotetext{
${ }^{2}$ Although anthropologist Gilberto Freyre $(1933,1966)$ was one of the most popular supporters of this theory in Brazil, this narrative of racial fraternity was also common in many other countries in Latin America; including Mexico (Vasconcelos 1925/1997), Cuba (De la Fuente 1999), Venezuela (Wright 2013), and Puerto Rico (González 1993).
} 
nearly doubled the percentage choosing to identify as negro (i.e., Afro-Brazilian) (Bailey 2008).

Second, data from the two last national censuses indicate that the proportion of the population self-identifying as black has increased for the first time since the 1940s. From 5\% of the total population in 1991, it increased to 6\% in 2000 and to $8 \%$ in 2010. What is still not entirely clear, however, is whether this recent increase reflects a new pattern of racial reclassification or if it is a result of demographic forces, such as different rates of fertility, mortality, and migration by racial categories. For instance, an increased pride in being ethnically black in this new institutional context may have influenced some individuals to start identifying as such in the censuses. Alternatively, the increase in the black population could also be the result of higher fertility rates among those who self-identify as black or increased migration of people selfidentifying as black from other developing countries, just to name two potential demographic forces.

In order to help shed some light on this issue, this study makes use of repeated cross-sectional data, together with information on mortality and migration rates, to infer the reasons for the observed changes in the size of the different racial categories over time. Commonly known in the demographic literature as the residual method, the core of this approach consists of comparisons between the observed and expected sizes of different cohorts over consecutive censuses (Himes and Clogg 1992; Perez and Hirschman 2009).

The results indicate that the growth in the "black" category since the 1990s has in fact been largely due to racial reclassification. At least 2.2 million of the 9 million people who self-identified as black in the 2000 census had not identified as such in 1990. Between 2000 and 2010 another 3 million people changed their racial identification from non-black to black. This trend was common among both men and women, and it was more heavily concentrated among the youth and young adults.

To help contextualize these findings, the next section provides a brief overview of the production of racial statistics in Brazil and the categories used. This is followed by a review of the available evidence on racial reclassification in the country and the demographic methods used in the analysis. After presenting the empirical results, the final section discusses some of the implications of these findings for future work on racial identification in Brazil.

\section{Racial statistics in Brazil}

The most recent Brazilian census, conducted in 2010, included a question on race: " $A$ sua cor ou raça é:" ("Your color or race is:"). Five options were available: branca 
(white), preta (black), parda (brown), amarela (yellow), and indígena (indigenous). In that year, $48 \%$ of the population self-identified as white, $43 \%$ as brown, $8 \%$ as black, $1 \%$ as yellow, and $0.4 \%$ as indigenous. These five terms have a long history in the national imagery of human races and have strongly shaped the way in which the Brazilian government has categorized the population in racial terms in its official statistics.

This classification system reflects the belief that four distinct populations have contributed to form the Brazilian population: European ("white"), African ("black"), Asian ("yellow”), and Native-Brazilian peoples (“indigenous”), while pardos ("brown”) represent the result of interracial births (Loveman 2009; Skidmore 1993). The emergence of this particular racialized worldview is associated with the European colonization and enslavement of populations in Africa, Asia, and the Americas and, as such, has not been exclusive to Brazil. For instance, the same historical process has strongly influenced the production of official statistics in other Latin American countries and in the United States (Smedley 2007; Wade 2010; Zuberi 2001).

In Brazil, this general classification system underlies all national censuses that have included a question on race, dating back to the first national count of 1872 . The Brazilian Census Bureau started to collect this information regularly in its decennial censuses in $1940^{3}$. In that year the race question included four categories: white, black, yellow, and brown. According to the Brazilian Census Bureau (2011), the yellow category was included mainly to account for the significant number of Japanese immigrants that entered the country between 1908 and 1930. In the 1940 census, 0.6\% of the population reported to be of Asian background. The indigenous category was introduced in the 1991 census, when $0.2 \%$ of the population self-identified as NativeBrazilian.

Some scholars have noted that, in everyday conversation, Brazilians frequently use terms other than the five included in the official census form to indicate racial categories. Chiefly, words other than pardo have been reported to indicate a person of mixed-race background (Harris 1970). The documentation of the Brazilian censuses indicates that when the respondents provided such terms, their answers were recoded by the Census Bureau to fit the prevailing official scheme. For instance, terms used to indicate racial mixture, such as mulatto and mestiço, were recorded in the published results as brown, and terms indicating Asian descent, such as Japanese and Chinese, were reported in the yellow category (Brazilian Census Bureau 1996, 2003).

\footnotetext{
${ }^{3}$ This is generally considered the first modern Brazilian census, since most of the legislation that created the Brazilian Census Bureau and made the data collection process more professional and consistent was passed in the 1930s (Senra 2006). After 1940 the only national count in which information on race was not asked was the 1970 census. Telles (2006:40-41) argued that this was the result of the strong opposition of the ruling military dictatorship to social demands organized around race. During the oppressive years of 1967 to 1974 , the mere mention of race was often considered an attack against the public order.
} 
It should also be noted that every census form instructed that one designated person (i.e., the head of the household or, in his or her absence, another "competent adult") should complete the census form per household, providing the requested information on all co-resident members. Therefore, the data on race collected in the Brazilian censuses is a mixture of self- and other-identification. Nonetheless, if individuals in the same household mostly agree on the racial identification of each coresident member, then self- and other-identification should provide largely the same information. In fact, studies that have compared data on self-identification and classification by an interviewer have found that this is generally the case. For instance, in a 1995 nationally representative sample of the urban population aged sixteen and over, $79 \%$ of the sample was consistently identified ${ }^{4}$ (Telles 2002). It is likely that individuals that share the same household show even higher rates of agreement, as they might share with each other their perspectives on their racial identities.

Overall, despite some small differences in the way the race question was phrased in the different national counts, the general pattern was consistent. The perspective that the Brazilian population could be classified in racial terms according to a scheme derived from four elementary populations (European, African, Native Brazilian, and Asian) and an absorbing mixed-race category has prevailed in the racial statistics produced in the country since the late 19th century.

\section{Earlier studies and open questions}

Although previous studies have investigated whether Brazilians tend to change their self-reported race over their lifetime, they have focused almost exclusively on the period between 1950 and 1990. Using data from the 1950, 1980, and 1991 censuses, these studies found a clear pattern of reclassification: while the number of people selfidentifying as black or white declined, the number of people in the brown category increased (Carvalho et al. 2004; Wood 1991; Wood and Carvalho 1994).

For instance, based on the mortality and migration rates prevailing in the period covered by their study, Carvalho et al. (2004) estimated that 10.2 million people who self-identified as brown in the 1950 census were expected to survive to the 1980 census, when this population reached ages 30 and older. However, 13.6 million people ages 30 and older actually identified as brown in the 1980 count. This indicates that at least 3.4 million people changed their racial identification to brown between 1950 and 1980 . Their results suggested that these 'new browns' were composed of 1.8 million individuals who had previously identified as white and 1.6 million who had identified

\footnotetext{
${ }^{4}$ The survey used the same five racial categories included in the 1991 census.
} 
Miranda: A resurgence of black identity in Brazil? Evidence from an analysis of recent censuses

as black. ${ }^{5}$ A similar trend was observed between 1980 and 1990, when the number of newly reclassified browns reached 1.9 million, and the white and black categories declined by 1.2 million and 0.6 million people, respectively (Table 1 ).

Two narratives offered in the literature might help explain this particular pattern of racial reclassification. One reason for this increased preference for mixed-raced racial identities might be related to the popularization of the ideology of racial democracy, originally formulated in the 1930s. As mentioned before, this narrative proposes that intense cultural and sexual mixing between Portuguese masters and African and indigenous slaves during colonial times facilitated the growth of a culture of racial tolerance in the country after the abolition of slavery in the 19th century. This claimed shared ancestry would be, therefore, a source of national pride and unity (Freyre 1933). The consolidation of this ideology in Brazilian popular culture over the course of the 20th century might help explain the increase in the number of individuals selfidentifying as brown between 1950 and 1990 .

\section{Table 1: $\quad$ Racial reclassification (in millions), by selected racial groups:} 1950 to 1990

\begin{tabular}{lccc}
\hline & \multicolumn{3}{c}{ Racial Category } \\
& White & Brown & Black \\
\hline Period 1950 to 1980: & & & \\
a) 1950 Enumerated population & 32.4 & 13.8 & 5.7 \\
b) 1980 Projected population, age 30+ & 25.1 & 10.2 & 4.1 \\
c) 1980 Enumerated population, age 30+ & 23.3 & 13.6 & 2.5 \\
d) Loss/Surplus due to reclassification (c-b) & -1.8 & 3.4 & -1.6 \\
e) \% Change due to reclassification (d/b) & -7.0 & 34.0 & -38.0 \\
Period 1980 to 1990: & & & \\
a) 1980 Enumerated population & 64.8 & 46.4 & 7.1 \\
b) 1990 Projected population, age 10+ & 59.3 & 43.5 & 6.5 \\
c) 1990 Enumerated population*, age 10+ & 58.0 & 45.4 & 5.9 \\
d) Loss/Surplus due to reclassification (c-b) & -1.2 & 1.9 & -0.6 \\
e) \% Change due to reclassification (d/b) & -2.0 & 4.0 & -10.0 \\
\hline
\end{tabular}

Note: *Carvalho et al. (2004) obtained the figures for this year by back-projecting the population enumerated in the 1991 census. Source: Tables 3, 4, and 7 in Carvalho et al. (2004).

${ }^{5}$ Longitudinal data would be necessary to strictly identify the previous racial identity of the 'new browns'. However, as Carvalho et al. (2004) note, it is likely that reclassification flows occurs more often between groups that represent close phenotypes. Flows between black-brown and between brown-white should be more common, while direct flows between the black category and the white category should be relatively rare. 
Another possible explanation for this pattern of racial reclassification lies in the fact that, in spite of the popular rhetoric of racial democracy, blackness still carries a strong social stigma in Brazil (Dzidzienyo 1971; Hasenbalg 1978; Nascimento 1989). Degler (1986:167) has argued, for instance, that individuals who self-identify as black tend to start self-identifying as brown after they have experienced social mobility - a process he called the "flight from blackness". Given the intensive industrialization and growth of the Brazilian economy during the 1960s and 1970s (Baer 2007), this process described by Degler might partially explain why, in relative terms, the "black" category lost a much larger share of individuals than the "white" category. For instance, while the "white" category decreased by $7 \%$ between 1950 and 1980 due to racial reclassification, the "black" category decreased by $38 \%$ (Table 1 ).

While these two narratives may offer some insight into the forces driving racial reclassification in Brazil between 1950 and 1990, more recent studies have suggested that new patterns emerged in the 1990s. In particular, in a comprehensive study of the Native-Brazilian population between the 1991 and 2000 censuses, Perz et al. (2008) found a large increase in the size of this population due to self-reclassification. They estimated that about 280,000 people who self-identified as indigenous in 1991 were expected to be alive in 2000, but 590,000 people ages nine and older identified as such that year. In other words, reclassified indígenas accounted for about half of the indigenous population ages nine and older in 2000.

Perz et al. (2008) suggest that this increase might be associated with the success of identity politics by indigenous movements after the redemocratization of Brazilian society in the mid-1980s. Following a broader literature on indigenous mobilization in Latin America, they argue that these social movements were able to make progress in valorizing indigenous identity and fighting representations which traditionally pictured indigeneity as backward and incompatible with modernity (Wade 2010; Warren 2001).

Black political activism also benefited from redemocratization. During the 1990s activists were able to organize public demonstrations that pressured the Brazilian state to acknowledge the existence of racial discrimination in the country. One example is the 1995 march in which thousands commemorated the 300th anniversary of the death of Zumbi dos Palmares, a popular leader of runaway slaves during colonial times. Organizations such as the Institute for Black Brazilian Women (Geledés Instituto da Mulher Negra) were created by black-movement activists, and by the mid-1990s President Fernando Henrique Cardoso became the first head of the Brazilian state to recognize racism in the country and to declare that the state should play a role in promoting racial justice (Telles 2006, Ribeiro 2008).

Nonetheless, concrete race-based affirmative action policies only started to appear in the early 2000s (Htun 2004). In 2001 Rio de Janeiro became the first state to pass legislation that reserved space in universities for Afro-Brazilians - or negros, the term 
Miranda: A resurgence of black identity in Brazil? Evidence from an analysis of recent censuses

most commonly used by black activists and the Brazilian government. Many other universities implemented similar policies in the following years and in 2012 a federal law demanded race-based quotas in the admission process of all universities operated by the federal government. In 2014 legislation also introduced race quotas in civil service jobs (Cristaldo 2012, Chagas 2014). It became a standard practice in these policies that individuals that self-identified as black or brown were considered AfroBrazilians.

Previous studies have argued that the introduction of race-based affirmative action policies might make it more likely that some individuals choose to self-identify as negros (Maggie 2005, Fry et al. 2007). For instance, Bailey (2008) used data from the 2002 Pesquisa Social Brasileira (PSEB) to investigate this hypothesis. Before being questioned about their racial identity, half of the sample in this survey was told that the government was creating job quotas for blacks and browns in the public sector and that this was an important issue ${ }^{6}$. Bailey found that, in an open-ended question on race, $8.8 \%$ of individuals identified as negro after quotas were mentioned and only $4.8 \%$ when quotas were not mentioned (2008, p. 602).

Nevertheless, in addition to the open-ended race question, the PSEB survey included the standard census race question. Interestingly, when race was measured this way the percentage of individuals self-identifying as brown or black was lower after job quotas were mentioned to respondents - although the effect is not statistically significant. When quotas were mentioned, $10.1 \%$ of respondents identified as black and $33.4 \%$ identified as brown. When quotas were not mentioned, these percentages were 11.5 and 34.9, respectively (Table 2).

To some extent, the different results in this split-ballot experiment of the openended and the census-format questions might indicate that a relationship between race quota awareness and identification with blackness existed in 2002, although this relationship might not have been very strong. After all, few universities had started to implement quotas at the time the PESB data was collected and federal legislation for job quotas only became a reality in 2014. Therefore, an important open question is whether the relationship found by Bailey (2008) became stronger over the course of the first decade of the 2000s, as affirmative action policies became more prevalent and the topic gained more space in the media. If this is the case, one might expect a substantial

\footnotetext{
${ }^{6}$ The exact introductory text was: "The subject of color and race is very important in Brazil. The government is now creating job quotas in the public sector for negros because they have had fewer opportunities than whites to obtain good public-sector jobs. Before this change, to get those public-sector jobs individuals took the same qualifying exams and those scoring best got the job. Now negros are guaranteed some good publicsector jobs even though their exam scores may not be the best.” (Bailey 2008, p. 600). Representative of the national adult Brazilian population, this public opinion poll covered a range of themes, such as racial identity and discrimination, public safety, social inequality, and reproductive rights. It was modeled after the General Social Survey conducted in the United States (Almeida, Schroeder, and Cheibub 2004).
} 
number of individuals changing their answers to the race question between the 2000 and 2010 census.

Table 2: $\quad$ Distribution of the adult population by race in the PESB survey, with and without the mentioning of job quotas for blacks and browns

\begin{tabular}{lcc}
\hline & \multicolumn{2}{c}{ Job Quotas } \\
& Not Mentioned & Mentioned \\
\hline White & 44.6 & 46.8 \\
& $(1.5)$ & $(1.4)$ \\
Brown & 34.9 & 33.4 \\
& $(1.4)$ & $(1.4)$ \\
Black & 11.5 & 10.1 \\
& $(1.0)$ & $(0.9)$ \\
Asian & 3.4 & 4.0 \\
& $(0.5)$ & $(0.6)$ \\
Indigenous & 5.7 & 5.7 \\
\multirow{2}{*}{ Total } & $(0.7)$ & $(0.7)$ \\
$\mathrm{N}$ & 100 & 100 \\
\hline
\end{tabular}

Notes: The PESB race question used here followed the format used in national censuses. Standard errors are shown in parentheses. Source: 2002 PESB.

The release of the data from the 2010 Brazilian census now makes it possible to investigate these questions. In particular, the present study uses demographic methods to examine whether a significant number of individuals self-reclassified as black after the increase of black political activism in the 1990s and the introduction of race-based affirmative action policies in the 2000s. Likewise, the addition of the 2010 data allows the examination of whether the resurgence of indigenous identity that took place in the 1990s continued into the 2000s.

\section{Analytic strategy and data}

Data from seven Brazilian censuses were used in this study. The 1940 and 1950 data are from the tabulations published by the Brazilian Census Bureau (1950, 1956). Data from the 1960 census are from the $1.25 \%$ sample distributed by the Centro de Estudos da Metrópole (Barbosa 2013). The 1980, 1991, and 2000 data are, respectively, from the 
Miranda: A resurgence of black identity in Brazil? Evidence from an analysis of recent censuses

5\%, 5.8\%, and the 6\% samples distributed by the Minnesota Population Center (2011). Data for 2010 is from the $10.7 \%$ sample provided by the Brazilian Census Bureau (2012a). All the seven censuses were household-based and used face-to-face interviews. ${ }^{7}$

Following previous studies of racial reclassification in Brazil, the residual method is used below to make inferences about the number of individuals that have changed their racial self-identification over their life course between two consecutive censuses. This technique has been used to investigate racial and ethnic reclassification in different societies, such as in the study of preference for whiteness in Puerto Rico (Loveman and Muniz 2007), the growth of the Irish and Native-American populations in the United States (Hout and Goldstein 1994; Passel 1976, 1997), and the decline of the Mexicanorigin population in that same country (Alba and Islam 2009).

The essence of this technique consists in following birth cohorts across censuses. It relies on one of the most basic propositions of demography: that changes in the size of a population between two points in time must be accounted for by the number of deaths, births, and migrations in that population during the time interval of observation (Perez and Hirschman 2009). Therefore, when a population is also defined by socially constructed boundaries such as race, if $P(0)$ is the size of a given birth cohort of individuals who self-identify as race $r$ at time 0 , the size of this birth cohort at time $t$ is:

$$
P(t)=P(0) \cdot S(0, t)+\Delta I(0, t)+\varepsilon(0, t)
$$

where $S(0, t)$ is the proportion of the cohort that survived between times 0 and $t, \Delta I(0, t)$ is the contribution of international migration ${ }^{8}$, and $\varepsilon(0, t)$ is the difference between the number of persons who entered and left the cohort between 0 and $t$ by changing racial categories.

If, for example, $\varepsilon(0, t)$ is a positive number, it can be inferred that the number of individuals who switched to race $r$ was larger than the number of individuals that switched from race $r$ to a race other than $r$. When $\varepsilon(0, t)$ equals zero, it can be inferred

\footnotetext{
${ }^{7}$ Although the size of the racial categories obtained using the micro-data and the fully tabulated census results are virtually identical (even for the smaller categories, such as Asian and Indigenous), micro-data were used whenever possible because not all the necessary information was available in the edited volumes published by the Census Bureau. For instance, the information required to estimate infant mortality by race was not consistently tabulated in all published results. The same is true for the size of the age groups presented in the published results. In order to maintain the most consistency in the projections, the micro-data were used to create age groups of the same size (i.e., 5 years) for all projection periods. Furthermore, some advanced tabulations were never published by the Census Bureau, such as those including information on the household member responsible for filling out the census questionnaire.

${ }^{8}$ In particular, $\Delta I(0, t)$ represents the difference between the number of immigrants to and emigrants from that cohort during the interval between 0 and $t$. An international immigrant at time $t$ is defined as an individual that entered the country between times 0 and $t$ and who is alive and residing in the country at time $t$.
} 
that either no person switched racial categories or that the flows of individuals entering and leaving race $r$ were of the same magnitude. In this sense, the expected size of this cohort at time $t$ under the assumption that no person changed racial identity between 0 and $t$ can be expressed as:

$$
P^{\exp }(t)=P(0) \cdot S(0, t)+\Delta I(0, t)
$$

When compared to the actual size of racial category $r$ at time $t, P^{\exp }(t)$ can be interpreted as an estimate of a counterfactual scenario - i.e., one in which individuals did not change racial categories over their life course. Three pieces of information are required to calculate the projected population $P^{\exp }(t)$ : population counts, information on intercensal mortality, and data on international migration. Since life tables by race were not readily available for Brazil, demographic estimation methods were used. Probabilities of dying before age three were estimated by race using the child survivorship method (Brass 1975) and a logit relational model was used to calculate complete life tables.

The 1998 and 2005 life tables for the general population provided by the Brazilian Census Bureau were used to derive the overall age pattern of mortality in the 1990s and 2000s, respectively (Brazilian Census Bureau 2012b). Hence, the parameter $\beta$ in the relational model was set to 1 and the level of mortality was allowed to vary by race through the parameter $\alpha$. For a detailed description of the technique used to estimate complete life tables from child mortality using the logit relation model, see United Nations (1983).

The child survivorship method and the logit relation model have been widely used to estimate life tables in the absence of reliable vital statistics data. This technique tends to be particularly robust in societies in which mortality is relatively low, as has been the situation in Brazil over the last two decades. However, as an indirect technique, this approach might be susceptible to estimation errors and biases emerging from data collection (Hill 1991, Preston et al. 2001). Of particular importance to the present study is the possibility of overestimating intercensal black mortality. If this were the case, a 'surplus' of self-identified blacks in a given census would not be due to racial reclassification, but an artifact arising from an estimated $P^{\exp }(t)$ that is lower than its proper value. In order to rule out this possibility, section 6 explores the extent to which the final results are sensitive to alternative mortality schedules.

As administrative or survey data on international migration is also unavailable, a few different scenarios were explored. After intercensal net international migration was estimated for the country as a whole it was calculated by race, assuming that migration flows were proportional to the size of each race group at the beginning of the decade. Given that previous studies have indicated that international migration to and from 
Miranda: A resurgence of black identity in Brazil? Evidence from an analysis of recent censuses

Brazil are relatively small in comparison to the total population, this simplifying assumption is a reasonable place to start the analysis (Carvalho and Campos 2006). Nevertheless, different assumptions about the selectivity of international migration by race are also explored in a separate section.

\section{Results}

In 1990, 7.3 million people self-identified as black. ${ }^{9}$ According to the estimated mortality rates prevailing in the following ten years, 6.8 million people ages ten and older were expected to self-identify as black in the 2000 census. However, the black category included 9 million people that year. This surplus implies that at least 2.2 million people in 2000 were newly reclassified blacks. In relative terms, this represents a net increase of $33 \%$ due to racial reclassification alone, which contrasts with the net decrease of $4 \%$ experienced by the black category in the 1980s, as documented by Carvalho et al. (2004). The estimates for the period between 2000 and 2010 show that the number of newly reclassified blacks continued to grow. While 9.9 million people aged ten and older were expected to self-identify as black in 2010, a total of 13 million people did so. In relative terms, this represents an increase of $31 \%$, similar to the rate for the previous decade (Table 3).

Longitudinal data would be necessary to identify the racial categories newly reclassified individuals previously self-identified with. However, it is likely that reclassification flows are more common between categories that represent similar phenotypes: flows between black and brown and between brown and white should be more common, while direct flows between the black and white categories should be more rare. Under this assumption, the estimates indicate that the brown category lost 3.6 million people to the white category and 2.2 million to the black category during the 1990s. ${ }^{10}$ Nevertheless, this loss was more than compensated for in the following decade. Over 10 million people who self-identified as white in 2000 decided to selfidentify as brown in 2010. Moreover, the standard errors indicate that the estimated racial reclassification to or from each racial category is statistically significant at conservative levels.

\footnotetext{
${ }^{9}$ In order to present the results on a decennial basis and to permit greater comparison with the existing estimates of racial reclassification in the literature, the population in the 1991 census was back-projected to 1990 when studying racial reclassification in the 1990s.

${ }^{10}$ Naturally, in practice some individuals might have switched directly between white and black. Therefore, in absence of longitudinal data to confirm the true prevalence of direct white to/from black reclassification, the results presented here should be interpreted with care.
} 
Table 3: Racial reclassification: 1990 to 2010

\begin{tabular}{llllll}
\hline & \multicolumn{5}{c}{ Racial Category } \\
& White & Brown & Black & Asian & Indigen. \\
\hline Period 1990 to 2000: & & & & & \\
a) 1990 Enumerated population & 74.7 & 61.5 & 7.3 & 0.6 & 0.3 \\
& $(0.017)$ & $(0.016)$ & $(0.007)$ & $(0.002)$ & $(0.002)$ \\
b) 2000 Projected population, age 10+ & 71.1 & 58.2 & 6.8 & 0.6 & 0.3 \\
& $(0.017)$ & $(0.016)$ & $(0.007)$ & $(0.002)$ & $(0.002)$ \\
c) 2000 Enumerated population, age 10+ & 74.7 & 52.0 & 9.0 & 0.7 & 0.6 \\
& $(0.017)$ & $(0.016)$ & $(0.008)$ & $(0.002)$ & $(0.002)$ \\
d) Change due to reclassification (c-b) & 3.6 & -6.2 & 2.2 & 0.1 & 0.3 \\
& $(0.005)$ & $(0.007)$ & $(0.004)$ & $(0.001)$ & $(0.002)$ \\
e) \% Change due to reclassification (d/b) & 5 & -11 & 33 & 16 & 112 \\
Period 2000 to 2010: & & & & & \\
a) 2000 Enumerated population & & & & & 0.7 \\
& 92.0 & 65.8 & 10.6 & 0.8 & $(0.002)$ \\
b) 2010 Projected population, age 10+ & $(0.018)$ & $(0.016)$ & $(0.008)$ & $(0.002)$ & $(0.002 .1$ \\
& 88.1 & 62.6 & 9.9 & 0.7 & 0.7 \\
c) 2010 Enumerated population, age 10+ & $(0.017)$ & $(0.016)$ & $(0.008)$ & $(0.002)$ & $(0.002)$ \\
& 77.8 & 68.8 & 13.0 & 1.8 & 0.6 \\
d) Change due to reclassification (c-b) & $(0.006)$ & $(0.006)$ & $(0.003)$ & $(0.001)$ & $(0.001)$ \\
e) \% Change due to reclassification (d/b) & -10.3 & 6.2 & 3.1 & 1.1 & -0.1 \\
\hline
\end{tabular}

Notes: Standard errors are shown in parentheses. The 1990 population was obtained by back-projecting the population in the 1991 census.

Source: Author's calculations based on the national censuses and estimated life tables.

Table 3 also shows that the surplus of Native Brazilians in the 1990s due to reclassification, noted by Perz et al. (2008), did not continue in the 2000s. In fact, the estimates indicate that the indigenous category lost approximately 100,000 members during the 2000s. The number of individuals self-identifying as Asian, on the other hand, was 159\% larger in 2010 than would be expected in the absence of racial reclassification. At least 1.1 million people who self-identified as Asian in 2010 had not done so in 2000. Asian ethnicity has been considerably less studied in Brazil than black and Native-Brazilian identities, and, to my knowledge, no previous study has discussed possible reasons for this increase. Therefore, future studies that explore the formation of 
racial identity among the population of Asian descent in Brazil might provide important contributions to the literature.

Breaking down the results by age and sex shows that the growth of the black category after the 1990s was common across different generations and took place among males and females (Table 4). Yet the results also show that it tended to be relatively more common among males and the younger generations. While the number of blacks aged ten to twenty-nine in 2000 was $39 \%$ greater due to racial reclassification, this figure was $22 \%$ among blacks ages sixty and older in that same year. The contrast was even higher in 2010, when these figures were $42 \%$ and $16 \%$, respectively. Finally, the estimates show that resurgence of indigenous and Asian ethnicities was also common between both sexes and across different generations. However, while gains to the Asian category were more common among the younger generations, gains to the indigenous category were more common among the older generations.

Table 4: Percent change in group size due to racial reclassification, by age and sex

\begin{tabular}{lccccc}
\hline & \multicolumn{2}{c}{ Sex } & \multicolumn{2}{c}{ Age (at the end of each decade) } \\
& Males & Females & $\begin{array}{c}\text { Youth and Young } \\
\text { Adults (ages: 10-29) }\end{array}$ & $\begin{array}{c}\text { Adults } \\
\text { (ages: 30-59) }\end{array}$ & $\begin{array}{c}\text { Older Adults } \\
\text { (ages: 60+) }\end{array}$ \\
\hline $\begin{array}{l}\text { Period 1990 to 2000: } \\
\text { White }\end{array}$ & 4 & 6 & 7 & 4 & 3 \\
Brown & -10 & -11 & -11 & -10 & -9 \\
Black & 37 & 29 & 39 & 30 & 22 \\
Asian & 15 & 17 & 19 & 14 & 16 \\
Indigenous & 107 & 118 & 87 & 136 & 180 \\
Period 2000 to 2010: & & & & \\
White & -12 & -12 & -14 & -11 & -8 \\
Brown & 9 & 11 & 10 & 9 & 11 \\
Black & 32 & 30 & 42 & 27 & 16 \\
Asian & 139 & 178 & 257 & 149 & 62 \\
Indigenous & -10 & -13 & -1 & -20 & -20 \\
\hline
\end{tabular}

Source: Author's calculations based on the national censuses and estimated life tables.

As mentioned before, the race data collected in the Brazilian censuses is a mixture of self- and other-identification, since a designated person is responsible for providing information on all his/her co-residents. Previous studies have also indicated that consistency between self- and other-identification tends to be high (Telles 2002). Nevertheless, it is interesting to investigate whether the increase in the number of people identifying as black was concentrated more heavily among those who reported 
their race directly or among those who had their race reported by a member of their household.

Such analysis is possible for the last decade, since the 2000 and 2010 counts recorded information on the household member that filled out the questionnaire. These data suggest that the increase in identification with blackness took place more intensively among those who reported their race directly in 2010. For clarity, I refer to those who reported their race directly as "ego-identified" respondents, and to those who had their race reported by a member of their household as "proxy-identified" respondents. Of the 10.6 million people that were enumerated as black in 2000, 3.2 million were ego-identified and 7.4 million were proxy-identified. In the 2010 census these numbers were 5.7 million and 7.3 million, respectively, for this same cohort of individuals (Table 5). Although the number of proxy-identified blacks remained relatively stable, the number of ego-identified blacks increased by 2.5 million, or $78 \%$.

Table 5: $\quad$ Change in the size of the black category between 2000 and 2010 (in millions), by type of person responsible for answering the survey

\begin{tabular}{lccc}
\hline & \multicolumn{3}{c}{ Respondent's race reported by } \\
& Co-resident member & Self & Total \\
\hline a) 2000 Enumerated population & 7.4 & 3.2 & 10.6 \\
b) 2010 Enumerated population, age 10+ & 7.3 & 5.7 & 13.0 \\
c) 2010 Projected population, age 10+ & 6.9 & 3.0 & 9.9 \\
d) Difference: b-c & 0.4 & 2.7 & 3.1 \\
\hline
\end{tabular}

Note: The projected population was calculated assuming that the household member responsible for answering the race question in 2000 would be the same in 2010. Source: author's calculations based on the national censuses and estimated life tables.

A simple exercise further puts these numbers into perspective. If the population reported in the 2000 census had been subjected to intercensal mortality and migration, but the answers to the race question and the household member responsible for answering the questionnaire had remained constant, one should expect 3.0 million egoidentified blacks and 6.9 million proxy-identified blacks in 2010 (Table 5, row c). This shows that even the category of blacks by proxy report received at least 0.4 million new members and that the estimated increase in the number of ego-identified blacks is about 2.7 million individuals (row d). A similar exercise was also conducted separately by age group, and the results show that the pattern described was common among both the youth and the adults (Table 6). 
Table 6: Change in the size of the black category between 2000 and 2010 (in millions), by age and type of person responsible for answering the survey

\begin{tabular}{llll}
\hline & \multicolumn{3}{c}{ Respondent's race reported by } \\
& Co-resident member & Self & Total \\
\hline Youth (ages 10 to 29 in 2010): & 3.4 & 0.3 & 3.7 \\
a) 2000 Enumerated population & 3.4 & 0.3 & 3.7 \\
b) 2010 Projected population & 3.5 & 1.8 & 5.2 \\
c) 2010 Enumerated population & 0.1 & 1.4 & 1.5 \\
d) Difference: c-b & & & \\
Younger adults (ages 30 to 59 in 2010): & 3.0 & 2.0 & 5.0 \\
a) 2000 Enumerated population & 2.9 & 1.9 & 4.8 \\
b) 2010 Projected population & 3.1 & 3.0 & 6.1 \\
c) 2010 Enumerated population & 0.2 & 1.1 & 1.3 \\
d) Difference: c-b & & & \\
Older adults (ages 60+ in 2010): & 1.0 & 0.9 & 1.9 \\
a) 2000 Enumerated population & 0.8 & 0.6 & 1.4 \\
b) 2010 Projected population & 0.7 & 0.9 & 1.6 \\
c) 2010 Enumerated population & -0.1 & 0.3 & 0.2 \\
d) Difference: c-b &
\end{tabular}

Note: The projected population was calculated assuming that the household member responsible for answering the race question in 2000 would be the same in 2010. Source: author's calculations based on the national censuses and estimated life tables.

It is possible that the increased identification with blackness observed in the 19902010 period is connected to broader historical processes that were taking place in Brazilian society even before the 1990s. To help shed some light on this question, the evidence available in the literature for the pre-1990 period was expanded by including data from two additional censuses: the 1940 and 1960 national counts. This permitted the first estimation of racial reclassification rates for the 1940s, 1950s, and the 1960-80 period. ${ }^{11}$ Since the race question was not asked in the 1970 census, a mean decadal reclassification rate for the 1960s and 1970s was obtained by dividing the estimated rate for the 1960-80 period by two. This is a simplification of the more complex procedure proposed by Carvalho et al. (2004) to convert a rate of reclassification to a decadal basis. Nonetheless, separate calculations showed that their more elaborate technique

\footnotetext{
${ }^{11}$ The child survival method and the model life tables presented by Frias and Rodrigues (1980) were used to estimate intercensal survival rates, following the same method described in section 4 for the 1990s and 2000s.
} 
and the simpler approach produced the same average decadal rate for the 1960s and 1970s in the present data (operations not shown).

The estimated rates of racial reclassification for the period between 1940 and 2010 are presented in Figure 1. They show that individuals have been leaving the "black" category at declining rates since the 1940s. For instance, 20\% of the population that self-identified as black in 1940 decided to identify as some other race in the 1950 census, presumably brown. But only $15 \%$ of people who self-identified as black in 1950 chose a different race in 1960. This rate declined further to $4 \%$ in the 1980 s. This broader historical picture suggests that, although the black category started to receive new members in the 1990s, the way Brazilians identify with blackness might have already been changing during previous decades.

Figure 1: Percent change in group size due to racial reclassification: 1940 to 2010

(a) White, brown, and black categories

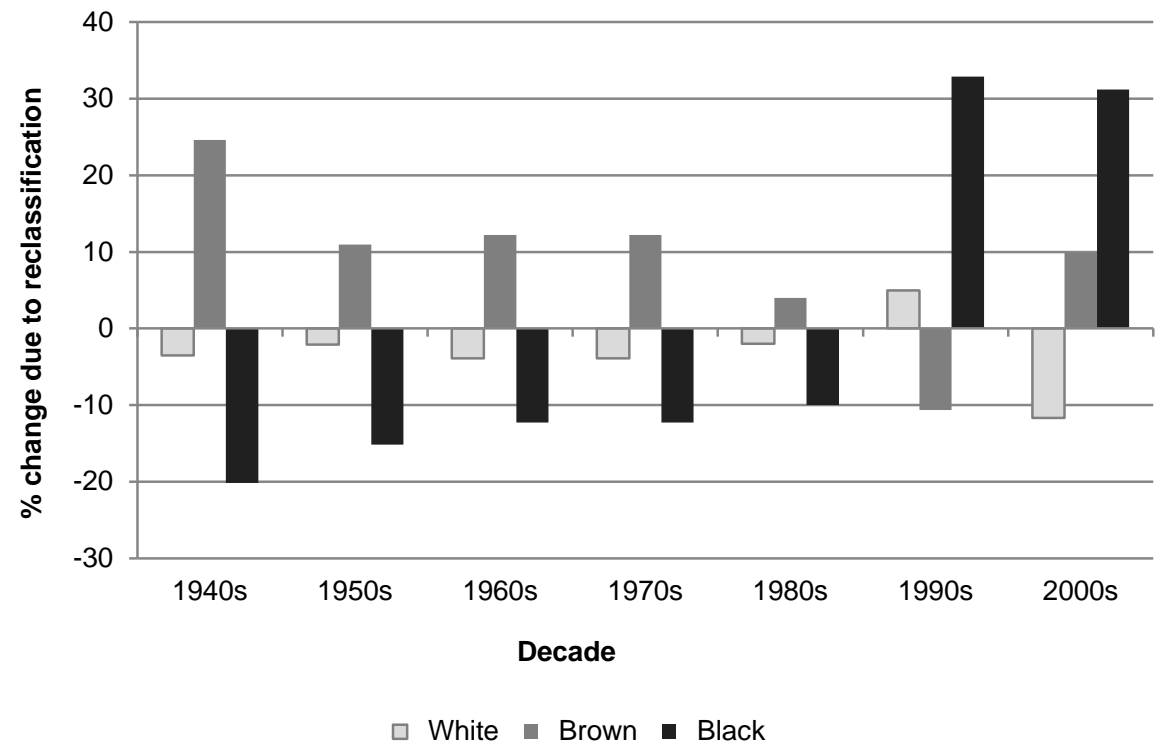


Figure 1: (Continued)

(b) Asian and indigenous categories

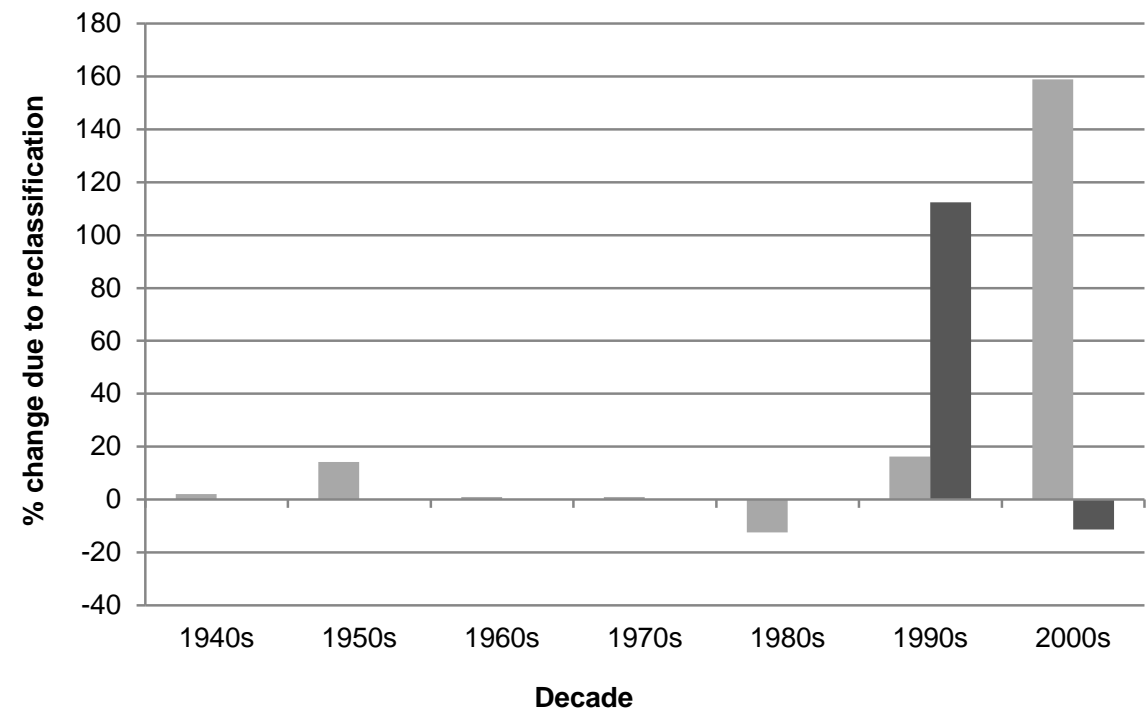

- Asian Indigenous

Note: rates for the 1960s and 1970s were obtained by dividing the rate for the $1960-80$ period by two. The indigenous category is only available after 1990 .

\section{Alternative scenarios: Mortality, international migration, and census coverage}

As mentioned above, data on intercensal mortality and international migration by race are necessary in other to estimate racial reclassification using the residual method. Since these data were not readily available they had to be estimated directly from the census data. Therefore, this section investigates whether the sharp increase in the number of individuals self-identifying as black between 1990 and 2010 is likely to be sensitive to the mortality and migration rates used in the previous section.

First, as explained in section 4, it might be argued that overestimated black mortality could be partially responsible for the estimated surplus of blacks in the 2000 and 2010 censuses. In order to explore this possibility, additional calculations were 
made using the life tables estimated for the white population to describe intercensal black mortality. Under this alternative scenario the results remained virtually unchanged. The number of newly reclassified blacks in 2000 declined from 2.2 million to 2.1 million, while no difference was observed in 2010 .

An even more conservative exercise is to consider an unrealistic hypothetical scenario in which no self-identified black person died between 1990 and 2010. This scenario would still imply a total of 1.7 million reclassified blacks in 2000, and 2.4 million in 2010 (i.e., row "c" minus row "a" in Table 3). Positive racial reclassification under such unrealistically low mortality rates reflects the fact that the gains to the black category due to reclassification more than compensated for the number of intercensal deaths. Although unrealistic, this scenario clearly illustrates the large extent of black racial reclassification during the last two decades.

Concerning international migration, it might be argued that the perceived increase in the number of blacks results from underestimating the number of in-migrants that self-identified as black. The results in the previous section used the simplifying assumption that international migration was proportional to the size of each racial category at the beginning of each decade. Fortunately, the Brazilians censuses include data that can be used to gauge whether this is a reasonable assumption: the respondents' country of residence five years before the census. This variable only partially captures intercensal international migration, since it does not include those who entered the country between six and ten years before the census, and those that emigrated. However, it can give some insight on the distribution of the in-migrant population by self-reported race.

Those who entered Brazil between 1995 and 2000 and between 2005 and 2000 were more likely to self-identify as white or Asian, and less likely to self-identify as black or brown, than the average population. For instance, while $8 \%$ of the nonimmigrant population self-identified as black in 2000, only $4 \%$ of the immigrant population did so. In 2010 these figures were $3 \%$ and 7\%, respectively (Table 7). These figures indicate that, in fact, the results in the previous section likely overestimate the number of black in-migrants. When estimating racial reclassification using the figures in Table 7 to weight international migration by race, the estimated number of newly reclassified blacks increased by about 100,000. Therefore, the findings in the previous section should be seen as a conservative estimate of racial reclassification to black. 
Table 7: Population ages ten and older, by self-reported race and country of residence five years previous to the census

\begin{tabular}{lcrcc}
\hline & \multicolumn{2}{c}{ 2000 census (\%) } & \multicolumn{2}{c}{ 2010 census (\%) } \\
& Abroad & Brazil & Abroad & Brazil \\
\hline White & 60.6 & 47.8 & 67.7 & 54.5 \\
Brown & 24.6 & 42.8 & 15.9 & 38.0 \\
Black & 4.1 & 7.9 & 3.1 & 6.6 \\
Asian & 9.8 & 1.1 & 12.4 & 0.5 \\
Indigenous & 0.8 & 0.4 & 0.9 & 0.4 \\
Total & 100 & 100 & 100 & 100 \\
\hline
\end{tabular}

Source: national censuses.

One final factor to consider is potential improvement in census coverage. It might be argued that the perceived increase in the number of blacks was not due to racial reclassification but to an improvement in census coverage over time. Although information on census undercount by self-reported race is not available, the postenumeration surveys conducted by the Brazilian Census Bureau provide some clues on what might be reasonable levels. These surveys indicate that $91.7 \%$ of the total population was enumerated in the 1991 census and $92.1 \%$ in the 2000 census ${ }^{12}$ (Oliveira et al. 2003:81). Using these coverage rates to correct the enumerated populations in the 1991 and 2000 census, the estimated number of newly reclassified blacks is 2.4 million people.

An additional scenario was examined to investigate the possibility that census undercount may have declined faster in the black population than in the general population. It was assumed that the coverage rate of the black population improved from $90 \%$ in 1991 , to $95 \%$ in 2000 , and to $100 \%$ in 2010 . At the same time, it was assumed that census coverage remained constant at 92\% between 1991 and 2010 in the rest of the population. Under this more extreme case, an estimated 2.0 million people would be newly reclassified blacks in 2000, and 2.6 million in 2010. In sum, the results of these exercises indicate that it is unlikely that the observed increase in the black population after the 1990s is an artifact of improvement in census coverage.

\footnotetext{
${ }^{12}$ At the time of writing, the Brazilian Census Bureau had not yet made the coverage rates for the 2010 census publicly available.
} 


\section{Conclusions and discussion}

Previous studies have documented a clear pattern of racial reclassification in Brazil over the second half of the 20th century: a large number of individuals changed their selfreported race from black or white to brown. However, an open question in the literature has been whether the increase in black political activism since the 1990s and the introduction of affirmative action policies during the 2000s are associated with a change in this historical pattern.

Using the residual method and repeated censuses, the analysis indicated that the "black" category gained at least 2.2 million newly reclassified members during the 1990s and 3.1 million new members during the first decade of the 2000s. This represents a rate of growth higher than 30\% per decade due to racial reclassification alone. The growth was even greater among the youth and young adults. A sensitivity analysis indicated that these results do not appear to depend on the estimated intercensal mortality and migration rates, and it was shown that these findings do not appear to be an artifact of improved census coverage either. Furthermore, an analysis of data from 1940 to 1990 suggests that identification with blackness might have been changing even before the 1990s. While the "black" category persistently lost population between 1940 and 1990, changing from black to brown seems to have been considerably more common in the 1940s than in the 1980s.

In sum, the findings show strong evidence that the period of increased black political activism in Brazil after the 1990s coincided with a sharp increase in the number of people self-identifying as black. Additional research will be necessary to disentangle the association between these two processes. On the one hand, the parallel with the indigenous population indicates some of the ways in which identity politics and racial reclassification might be connected in the Brazilian context. For instance, the progress made by indigenous movements in altering "the political, symbolic, and material meanings" (Perz et al. 2008:11) attached to indigenous identity was intrinsically connected to the increase in the number of people self-identifying as indigenous after the redemocratization of the Brazilian society in the mid-1980s (Warren 2001). As discussed above, a similar process of political mobilization has also taken place among black activists over the last two decades.

On the other hand, the situations of the indigenous and the black populations differ in considerable ways. For instance, while the black population is more urban and concentrated in the more industrialized southern part of the country, the indigenous population resides mostly in rural areas in the less densely populated northern region. Future research will need to investigate how these different circumstances impacted the connection between identity politics and racial reclassification in these two groups. 
Past studies have suggested that the introduction of race-based quotas might increase the likelihood that individuals self-identify as black or brown (or negro) as opposed to white (Maggie 2005, Fry et al. 2007, Bailey 2008). The findings in the present study also provide an important contribution to this debate. To a certain extent, the fact that over 3 million people started to identify as black between 2000 and 2010, the period in which race-based quotas were implemented in the access to higher education, suggests that there might have been a connection between these two processes.

However, the findings indicate that racial quotas alone might not tell the whole story, since in the 1990s there was already a similarly large increase in identification with blackness. One important interpretation of these new findings is that the literature might need to pay greater attention to studying racial quotas as both cause and consequence of the increased identification with blackness in Brazil. While quotas might have influenced racial reclassification in the earlier 2000s, the large number of people reclassifying as black in the 1990s might also have contributed to the passing of affirmative action policies in the first place. The higher number of individuals identifying as black might have helped to strengthen the political pressure black activists needed to enforce institutional changes, including the system of racial quotas and also other state policies such as the creation of the Ministry for the Promotion of Racial Equality in 2003.

One final theme to be considered is the potential association between social mobility and racial identification. Previous studies have argued that in Brazil, "money whitens" and "poverty darkens". Therefore, an alternative explanation for the increase in the black category after the 1990s is that it reflects downward social mobility among a segment of the population instead of a re-valorization of black identity. This seems an unlikely explanation, however, since there has been a particularly sharp decline in poverty rates and income inequality in Brazil over the last two decades. For instance, the proportion of the population living in poverty declined from 31.5\% to $8.5 \%$ between 1992 and 2012 (IPEA 2013:18).

On a methodological note, the results of this study also indicate that the collection of longitudinal data on racial identification, in the form of qualitative and large-survey studies, has the potential to greatly contribute to the understanding of racial politics in contemporary Brazil. With repeated cross-sectional data, it was possible to investigate covariates that change in a predictable fashion over time (e.g., age) or that are time invariant (e.g., sex). Large-scale and ethnographic longitudinal data can provide a more complete picture of who the individuals that are changing their racial identification are and, ultimately, what this process might mean to them. 


\section{Acknowledgments}

I thank Herbert Smith, Tukufu Zuberi, Emilio Parrado, and Kristen Harknett for their comments on earlier versions of this manuscript. I am also very thankful to the editor and three anonymous reviewers for their insightful comments and suggestions. 


\section{References}

Alba, R. and Islam, T. (2009). The Case of the Disappearing Mexican Americans: An Ethnic-Identity Mystery. Population Research and Policy Review 28(2): 109121. doi:10.1007/s11113-008-9081-x.

Almeida, A.C., Schroeder, A., and Cheibub, Z. (2004). PESB: Pesquisa Social Brasileira 2002 [electronic resource]. Rio de Janeiro: Universidade Federal Fluminense. http://www.cis.org.br.

Baer, W. (2007). The Brazilian Economy: Growth and Development. Boulder, CO: Lynne Rienner Publishers.

Bailey, S.R. (2008). Unmixing for race making in Brazil. American Journal of Sociology 114(3): 577-614.

Barbosa, R.J. (2013). Nota Técnica: Instruções para o Uso dos Bancos de Microdados das Amostras dos Censos Demográficos Brasileiros (1960 a 2010). University of São Paulo: Centro de Estudos da Metrópole.

Brass, W. (1975). Methods for estimating fertility and mortality from limited and defective data. Chapel Hill: University of North Carolina, Laboratories for Population Statistics.

Brazilian Census Bureau (1950). Censo Demográfico: População e Habitação. Rio de Janeiro: IBGE.

Brazilian Census Bureau (1956). Brasil: Censo Demográfico. Rio de Janeiro: IBGE.

Brazilian Census Bureau (1996). Censo Demográfico, 1991: Características Gerais da População e Instrução. Resultados da Amostra. Rio de Janeiro: IBGE.

Brazilian Census Bureau (2003). Censo Demográfico 2000: Características Gerais da População. Resultados da Amostra. Rio de Janeiro: IBGE.

Brazilian Census Bureau (2011). Características Étnico-Raciais da População: Um Estudo das Categorias de Classificação de Cor ou Raça, 2008. Rio de Janeiro: IBGE.

Brazilian Census Bureau (2012a). Censo Demográfico 2010: Resultados Gerais Da Amostra. Rio de Janeiro: IBGE.

Brazilian Census Bureau (2012b). Tábua Completa de Mortalidade. Rio de Janeiro: IBGE.

Chagas, P.V. (2014). Lei de Cotas no serviço público é sancionada. Agência Brasil. 
Cristaldo, H. (2012). Dilma assina decreto que regulamenta Lei de Cotas. Agência Brasil.

de Carvalho, J.A.M. and de Campos, M.B. (2006). A variação do saldo migratório internacional do Brasil. Estudos Avançados 20(57): 55-58. doi:10.1590/S010340142006000200005.

de Carvalho, J.A.M., Wood, C.H., and Andrade, F.C.D. (2004). Estimating the stability of census-based racial/ethnic classifications: The case of Brazil. Population Studies 58(3): 331-343. doi:10.1080/0032472042000272375.

de la Fuente, A. (1999). Myths of Racial Democracy: Cuba, 1900-1912. Latin American Research Review 34(3): 39-73.

Degler, C.N. (1986). Neither Black Nor White: Slavery and Race Relations in Brazil and the United States. Madison: University of Wisconsin Press.

do Nascimento, A. (1989). Brazil, mixture or massacre? Essays in the genocide of a Black people. Dover, MA: Majority Press.

Dzidzienyo, A. (1971). The Position of Blacks in Brazilian Society. London: Minority Rights Group.

Freyre, G. (1933). Casa-grande \& senzala, edição crítica. Madrid: Allca XX.

Freyre, G. (1966). The Racial Factor in Contemporary Politics. Brighton: University of Sussex.

Frias, L.A.M. and Rodrigues, P. (1980). Brasil: tábuas-modelo de mortalidade e populações estáveis. Rio de Janeiro: IBGE.

Fry, P., Maggie, Y., Maio, M.C., Monteiro, S., and Santos, R.V. (2007). Divisões perigosas: políticas raciais no Brasil contemporâneo. Rio de Janeiro: Civilização Brasileira.

González, J.L. (1993). Puerto Rico: the four-storeyed country and other essays. Princeton: M. Wiener Pub.

Hanchard, M. (eds.) (1999). Racial Politics in Contemporary Brazil. Durham and London: Duke University Press. doi:10.1215/9780822382539.

Harris, M. (1970). Referential Ambiguity in the Calculus of Brazilian Racial Identity. Southwestern Journal of Anthropology 26(1): 1-14.

Hasenbalg, C.A. (1978). Race relations in post-abolition Brazil: The smooth preservation of racial inequalities. University of California, Berkeley. 
Miranda: A resurgence of black identity in Brazil? Evidence from an analysis of recent censuses

Hill, K. (1991). Approaches to the Measurement of Childhood Mortality: A Comparative Review. Population Index 57(3): 368-382. doi:10.2307/3643873.

Himes, C.L. and Clogg, C.C. (1992). An Overview of Demographic Analysis as a Method for Evaluating Census Coverage in the United States. Population Index 58(4): 587-607. doi:10.2307/3644491.

Hout, M. and Goldstein, J.R. (1994). How 4.5 Million Irish Immigrants Became 40 Million Irish Americans: Demographic and Subjective Aspects of the Ethnic Composition of White Americans. American Sociological Review 59(1): 64-82. doi:10.2307/2096133.

Htun, M. (2004). From "Racial Democracy" to Affirmative Action: Changing State Policy on Race in Brazil. Latin American Research Review 39(1): 60-89. doi:10.1353/lar.2004.0010.

IPEA (2013). Duas Décadas de Desigualdade e Pobreza no Brasil Medidas pela PNAD/IBGE. Comunicados do IPEA 159: 1-47.

Loveman, M. (2009). The Race to Progress: Census Taking and Nation Making in Brazil (1870-1920). Hispanic American Historical Review 89(3): 435-470. doi:10.1215/00182168-2009-002.

Loveman, M. and Muniz, J.O. (2007). How Puerto Rico Became White: Boundary Dynamics and Intercensus Racial Reclassification. American Sociological Review 72(6): 915-939. doi:10.1177/000312240707200604.

Maggie, Y. (2005). Políticas de cotas e o vestibular da UnB ou a marca que cria sociedades divididas. Horizontes Antropológicos 11(23): 286-291. doi:10.1590/ S0104-71832005000100029

Minnesota Population Center (2011). Integrated Public Use Microdata Series, International: Version 6.1. Minneapolis: University of Minnesota.

Oliveira, L.C., de Freitas, M.P.S., Dias, M.R.M.L., Nascimento, C.M.F., da Silva Mattos, E., and Ramalho, J.J.A. (2003). Censo Demográfico 2000: Resultados da Pesquisa de Avaliação da Cobertura da Coleta. Textos para Discussão 9.

Passel, J.S. (1976). Provisional evaluation of the 1970 census count of American Indians. Demography 13(3): 397-409. doi:10.2307/2060536.

Passel, J.S. (1997). The growing American Indian population, 1960-1990: Beyond demography. Population Research and Policy Review 16(1-2): 11-31. doi:10.1023/a:1005724610787. 
Perez, A.D. and Hirschman, C. (2009). 2. Estimating Net Interracial Mobility in the United States: A Residual Methods Approach. Sociological Methodology 39(1): 31-71. doi:10.1111/j.1467-9531.2009.01220.x.

Perz, S.G., Warren, J., and Kennedy, D.P. (2008). Contributions of Racial-Ethnic Reclassification and Demographic Processes to Indigenous Population Resurgence: The Case of Brazil. Latin American Research Review 43(2): 7-33. doi:10.1353/lar.0.0019.

Preston, S. H., Heuveline, P., and Guillot, M. (2001). Demography: measuring and modeling population processes. Malden, MA: Blackwell Publishers.

Ribeiro, M. (2008). Mulheres negras: uma trajetória de criatividade, determinação e organização. Revista Estudos Feministas 16(3): 987-1004. doi:10.1590/S0104026 X2008000300017.

Senra, N.d.C. (2006). História Das Estatísticas Brasileiras: Estatisticas Desejadas (1822 - c.1889). Rio de Janeiro: Instituto Brasileiro de Geografia e Estatística.

SEPPIR (2014). Relatório de Gestão Do Exercício de 2013. Brasília: Presidência da República do Brasil.

Skidmore, T.E. (1993). Black into White: Race and Nationality in Brazilian Thought. Durham and London: Duke University Press. doi:10.1215/9780822381761.

Smedley, A. (2007). Race in North America: the Origin and Evolution of a Worldview. Boulder, Colo: Westview Press.

Telles, E.E. (2002). Racial ambiguity among the Brazilian population. Ethnic and Racial Studies 25(3): 415-441. doi:10.1080/01419870252932133.

Telles, E.E. (2006). Race in another America: the significance of skin color in Brazil. Princeton, N.J.: Princeton University Press.

United Nations (1983). Manual X: Indirect techniques for demographic estimation. New York: United Nations Department of Economic and Social Affairs.

Vasconcelos, J. (1925/1979). The Cosmic Race / La Raza Cosmica. Baltimore: Johns Hopkins University Press.

Wade, P. (2010). Race and ethnicity in Latin America. New York: Pluto Press.

Warren, J.W. (2001). Racial Revolutions: Antiracism and Indian Resurgence Brazil. Durham and London: Duke University Press. doi:10.1215/9780822381303. 
Miranda: A resurgence of black identity in Brazil? Evidence from an analysis of recent censuses

Wood, C.H. (1991). Categorias censitarias e classificações subjetivas de raça no Brasil. In: Lovell, P.A. and Bercovich, A. (eds.). Desigualdade racial no Brasil contemporâneo. Belo Horizonte: UFMG: 93-111 .

Wood, C.H. and de Carvalho, J.A.M. (1994). Categorias do Censo e Classificação Subjetiva de Cor no Brazil. Revista Brasileira de Estudos Populacionais 11(1): 3-17.

Wright, W.R. (2013). Café con leche race, class, and national image in Venezuela. Austin: University of Texas Press.

Zuberi, T. (2001). Thicker than blood: how racial statistics lie. Minneapolis: University of Minnesota Press. 